\title{
Review on COVID-19: Rise of SARS-CoV-2 Pandemic Outbreak
}

Vidhan Chand Bala ${ }^{*}$ (D)
Punet Kumar ${ }^{2}$
1Department of Pharmacology, Oxford
College of Pharmacy, Ghaziabad, Uttar
Pradesh, India
2Department of Pharmaceutical
Chemistry, Shri Gopichand College of
Pharmacy, Harchandpur, Uttar
Pradesh, India
*email: vidhanchandbala07@gmail.com
Keywords:
2019-nCoV
Coronavirus
COVID-19
MERS-CoV
SARS-CoV-2

\begin{abstract}
Initially recognized of COVID-19 within the world in 2019, the World Health Organization situational report from May 22nd, 2020, globally, there is a complete of 5,204,508 confirmed cases, with 212 countries being affected by the novel coronavirus. 2019 novel coronavirus (SARS-CoV-2) is that the seventh member of the family of coronaviruses is enveloped viruses with a positive sense, singlestranded RNA genome. The SARS-CoV-2 may be a $\beta-\mathrm{CoV}$ of group $2 \mathrm{~B}$ there is $70 \%$ comparability in genetic sequence to SARS-CoV. The source of the new coronavirus infection has been resolved as bats. With whole-genome sequences of SARS-CoV-2 is $96 \%$ comparatively at the whole-genome level to a bat coronavirus. Mechanisms of transmission are concluded to incorporate contact, droplet, and possibly airborne under certain circumstances supported ancient experiences associated with SARS-CoV outbreaks. Although antiretroviral therapy is being widely used everywhere the globe for such patents, effects at finding a SARS-CoV vaccine haven't succeeded so far.
\end{abstract}

Received: May 26th, 2020

Accepted: June 17th, 2020

Published: June 22nd, 2020

(C) 2020 Vidhan Chand Bala, Punet Kumar. Published by Institute for Research and Community Services Universitas Muhammadiyah Palangkaraya. This is an Open Access article under the CC-BY-SA License (http://creativecommons.org/licenses/by-sa/4.0/). DOI: https://doi.org/10.33084/bjop.v3iSpecial-1.1412

\section{INTRODUCTION}

Since the initial recognition of COVID-19 in the world in 2019, tremendous advances have taken place in the understanding of the dreaded diseases as regarding its epidemiology, etiology, immunology, Pathophysiology, clinical feature, and morphology changes in various tissues and organs of the body. Although antiretroviral therapy is being widely used all over the world for such patents, effects at finding a 2019 Novel Coronavirus (SARS-CoV-2) vaccine have not succeeded. Human pathogenic subtypes of a coronavirus are associated with mild clinical manifestations. However, SARS-CoV and MERS-CoV are two important exceptions. In 2012, MERS-CoV was first seen in Saudi Arabia. He was responsible for 2,494 confirmed cases, leaving 858 people dead. In 2002, a subtype of the Corona beta virus spread rapidly in Guangdong, China. This epidemic has claimed 8,000 deaths and 774 deaths in 37 countries (Lu et al., 2020). The epidemic of 2020 was detected as pneumonia of unknown etiologic in Wuhan, China. Extensive studies and laboratory research have identified the offender as a new strain of a coronavirus (Adhikari et al., 2020).

Initially, this virus was classified as SARS-CoV-2. However, the virus was classified by the International Commission for Viruses Classification as CoV-2. On February $11^{\text {th }}$, 2020, the World Health Organization (WHO) announced that the disease caused by this new virus was Coronavirus 2019 (COVID-19). The emergence and outbreak of frequent coronaviruses pose a public health threat. This recommends that $\mathrm{CoVs}$ that originate from one animal to another can be transferred from one person to another. The ongoing changes in the 
environment and climate make the emergence of such infections in the future more likely (Hassan et al., 2020).

\section{EPIDEMIOLOGY}

COVID-19 is pandemic in the spread and is seen in all continents. As per the WHO global report 2019, a novel coronavirus recognizing SARS-CoV-2. This is likely the third time in three decades that a zoonotic coronavirus has fall from infecting animals to humans. As of May 25 ${ }^{\text {th }}$, 2020,337,687 have died, and 5,204,508 have been infected globally with the center of the outbreak being located in Wuhan but now having spread, with confirmed cases 212 other countries (Worldometer, 2020). While the fatality rate of SARS-CoV-2 is less than other recent respiratory virus outbreaks, it rests much higher than other commonly encountered causes of respiratory infection but its full impact is yet undetermined. The WHO has now conformed the coronavirus outbreak to be a public health emergency of international concern (Long \& Ehrenfeld, 2020). Most infected countries' data of COVID-19 are summarized in Figure 1.

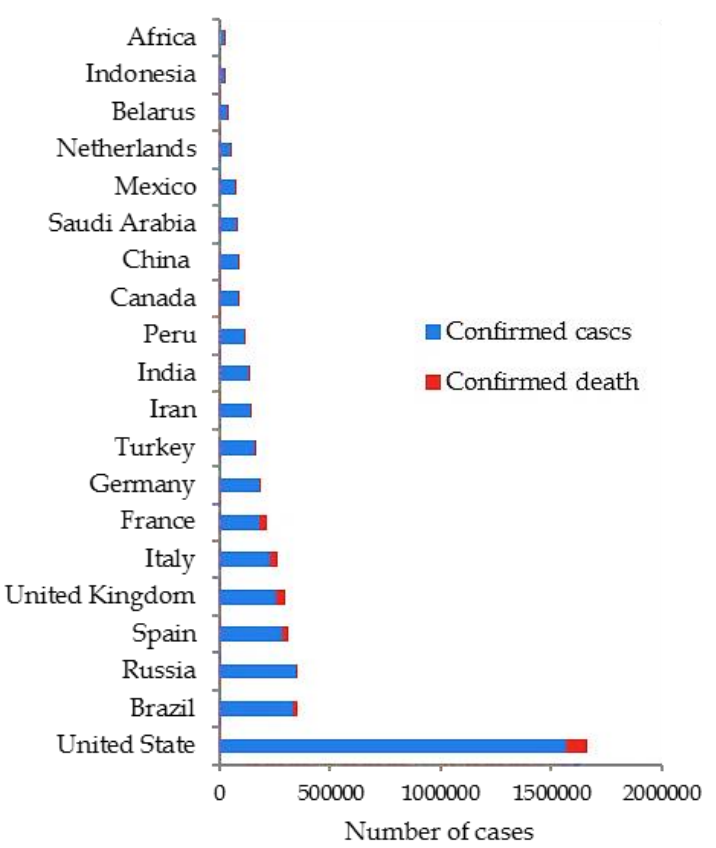

Figure 1. COVID-19 spread and is seen in all continents per May 25 ${ }^{\text {th }}, 2020$ (Worldometer, 2020)
Many studies show more clearly that the death rate increases with age, and children younger than 9 years do not appear to be affected significantly, without symptoms or mild symptoms or none of them died due to a COVID-19 infection. For 80-year-olds, about $14.80 \%$ of people die as presented in Figure 2. Mortality begins to increase for those over 50 years of age. The death rate among people under fifty is $0.02 \%$, while it is $0.8 \%$ for those aged 18-44. For ages 45 to 64 years, the ratio is $3.60 \%$, for ages 65 to 79 years is $8.00 \%$ and for people over 80 years old is $14.8 \%$ (Worldometer, 2020).

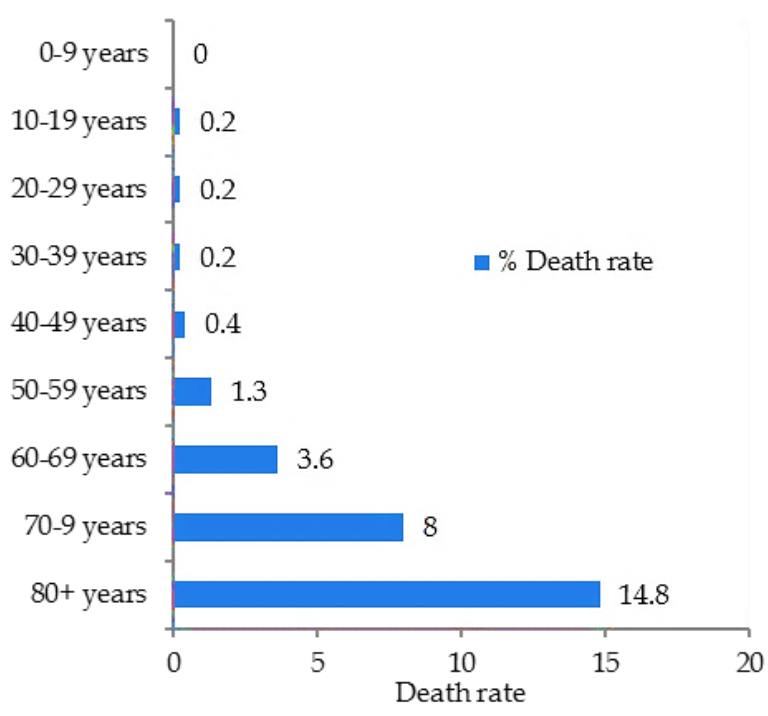

Figure 2. The COVID-19 death rate in different age groups per May 25th 2020 (Worldometer, 2020)

The elderly and young people, who suffer from serious diseases, such as diabetes and heart and lung diseases, are at risk of developing a serious disease if they have a coronavirus. The death rate for those without preexisting conditions is around $1 \%$. The Centers for Disease Control and Prevention has published specific guidelines for people in these categories (Hafeez et al., 2020). For people with cardiovascular disease, the death rate is $13.2 \%$, for diabetes $9.2 \%$, for chronic respiratory diseases (such as asthma and chronic lung disease) 8.0\%, for high blood pressure (high blood level) $8.4 \%$, and the cancer death rate $7.6 \%$. The data is summarized in Figure 3. 


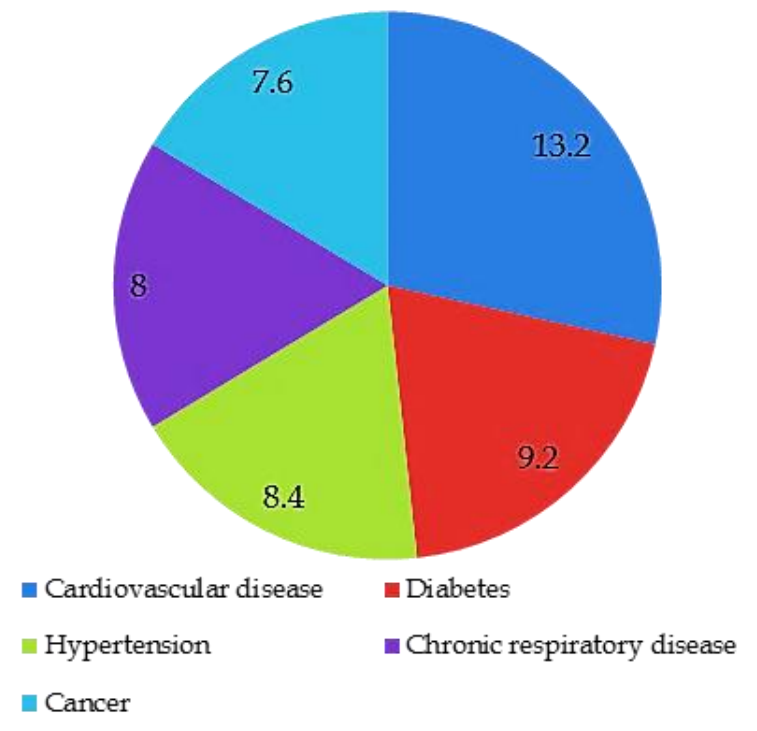

Figure 3. COVID-19 death rate by pre-existing health condition per May 25 ${ }^{\text {th }}, 2020$ (Worldometer, 2020)

\section{ETIOLOGICAL OF COVID-19}

COVID-19 is caused by a single-stranded RNA (retrovirus) virus called the 2019 Novel Coronavirus (SARS-CoV-2). The 2019 Novel Coronavirus or 2019$\mathrm{nCoV}$ is called the Wuhan Virus because it is a never before seen mutation of an animal coronavirus first identified in Wuhan, China, on December 30 ${ }^{\text {th }}, 2019$. The SARS-CoV-2 is a novel human coronavirus in further to similar coronavirus 229E, NL 63, OC43, HKU1, Middle East respiratory syndrome-related coronavirus (MERS$\mathrm{CoV}$ ) and severe acute respiratory syndrome-related coronavirus (SARS-CoV) (Zhu et al., 2020). The SARS$\mathrm{CoV}-2$ is the seventh member of the coronavirus family (Nidovirales arrangement, Coronaviridae family, and Coronavirinae subgroup) are positive-encapsulated viruses, single-chain RNA genome. With genome sizes feeding on 26 to $32 \mathrm{~kb}$ in length, coronaviruses possess the largest genomes of human RNA viruses, after MERSCoV and SARS-CoV (Dhama et al., 2014; Hui et al., 2020). Thanks to the genome sequencing, the nCoV 2019 gene sequencing became available to the $\mathrm{WHO}$, which enabled various laboratories to produce a diagnostic test for the reverse transcription of a polymerase chain reaction (RT-PCR) specifically for detection of 'viral DNA. The SARS-CoV-2 is the $2 \mathrm{~B} \beta-\mathrm{CoV}$ group. With genetic comparability of more than $70 \%$ with SARS-CoV (Li et al., 2020). Coronaviruses have begun two large-scale pandemics in the past two decades, SARS and the Middle East respiratory syndrome (MERS) (Drosten et al., 2003; Zaki et al., 2012). It has commonly been thought that SARS-CoV-2 which is found in bats could cause a disease outbreak (Fan et al., 2019; Schoeman \& Fielding, 2019).

\section{ORIGIN OF SARS-CoV-2}

The source of the new coronavirus infection has been resolved as a racket. With the entire genome, the SARSCoV-2 sequences are $96 \%$ identical at the full genome level of the interactive Coronavirus (Zhou et al., 2020). Wu and his colleagues note a genetic analysis of the genetic development of the complete viral genome and conclude that the virus was closely related to a group of SARS coronaviruses that were previously sampled on bats in China (Wu et al., 2020a). Ji and colleagues note a complete sequence analysis and comparison in conjunction with the relative polarization of the use of equivalent codon (RSCU) among animal species based on the SARS-CoV2 RNA genome sequences, and results show that the virus was a combined virus between a bat coronavirus and another unknown origin coronavirus. They also noticed that the snake was the animal's most likely reservoir due to the RSCU bias of the virus being closest to the snake (Ji et al., 2020). The new coronavirus has demonstrated a similar pattern of infection with other coronaviruses in humans, especially the SARS-CoV and MERS-CoV (Guo et al., 2020; Kumar et al., 2020).

\section{COMPOSITION OF SARS-CoV-2}

Coronary viruses are spherical with diameters of approximately $125 \mathrm{~nm}$, as demonstrated in recent studies 
by microscopic tomography and electron microscopy. A major characteristic feature of coronaviruses is that clubdropping points emanate from the surface of the virion. These nails are an explanatory feature of the virion and give it the appearance of a solar aura, which gave the name of a coronavirus. In the shell of the virion is the nucleus. Coronaviruses have a unified helical nucleocapsid, which is not unusual for positive RNA viruses but is more common for negative RNA viruses (Barcena et al., 2009).

The structure of the coronavirus contains four major structural proteins as visualized in Figure 4. These are advanced proteins $(\mathrm{S})$ membranous proteins $(\mathrm{M})$ casing proteins (E) and nucleocapsid proteins $(\mathrm{N})$ all encoded at the three 'ends of the viral genome. Protein S ( 150 kDa), uses the $\mathrm{N}$-terminal signal sequence to access the ER, and it is strongly bound to glycosylate. Homotrimers from the virus-encoded protein $S$ produce a distinct peak structure on the surface of the virus. COVID-19 glycoprotein S could be a first-class fusion protein and a successful binding to the host receptor. In most coronaviruses, $\mathrm{S}$ is divided by angry protease in a group of cells into several different peptides denoting S1 (receptor binding domains) and S2 (advanced molecule) (Schoeman \& Fielding, 2019).

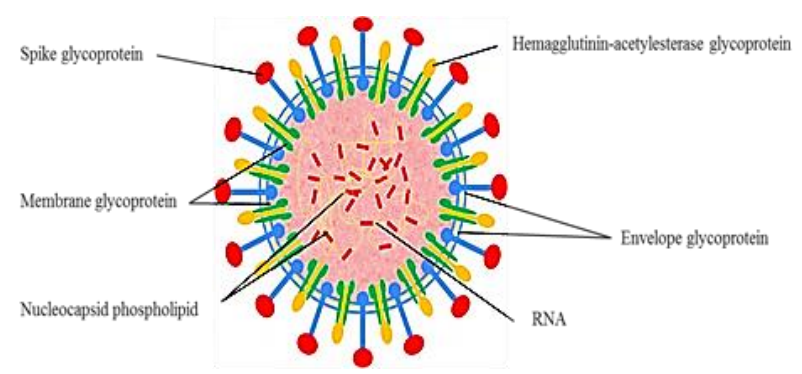

Figure 4. Schematic diagram of coronavirus present different membrane proteins

Protein $\mathrm{M}$ is the most abundant structural protein in Freon. It is a very weak protein $(\sim 25-30 \mathrm{kDa})$ with three membranous domains (Molenkamp \& Spaan, 1997) and is supposed to transport virion in its shape. It is a low ectodomain $\mathrm{N}$-terminal glycosylated and a much larger C-terminal endo domain extends 6 to $8 \mathrm{~nm}$ in the viral structure (Kuo \& Masters, 2013). Although the translation is common to the ER membrane, most M proteins do not have the code sequence (Hurst et al., 2013).

Protein E ( 8-12 kDa) is found in small quantities in the Freon. Coronavirus E proteins vary greatly but have a typical structure (Sturman et al., 1980). The membrane topology for protein $\mathrm{E}$ has not been completely resolved, but most data indicate that it is a transmembrane protein. Protein E contains the ectoderm N-terminal field and the C-terminal endodomain and the ion channel activity. Since they are hostile to other structural proteins, recombinant viruses that lack protein $\mathrm{E}$ are not always fatal, although this may depend on the type of virus (Klausegger et al., 1999).

Protein $\mathrm{N}$ is the only protein found in the nucleus. It consists of two different fields, the N-domain (NTD) and the C-field (CTD), both of which can bind to RNA in the laboratory, but each field uses different mechanisms to link RNA. Protein N is also graters phosphorylated, and phosphorylation has been recommended to make a structural change that improves viral RNA affinity compared to non-viral RNA. Protein N links the viral genome with string-like beads. Specific cRNAs substrates were identified for protein N; TRS and genomic packing signal. Genomic conditioning signal is individually associated with the second domain or the terminal RNA binding field. $\mathrm{N}$ protein also binds nsp3 receptor protein, a key component of the replicate complex protein, and the M protein (McBride et al., 2014). A fifth structural protein, hemagglutinin esterase $(\mathrm{HE})$, is here in a subset of $\beta-\mathrm{CoV}$. Protein works like hemagglutinin bind to sialic acids with glycoproteins on the surface and contains acetyl esterase activity (Graham et al., 2005). These activities are believed to prolong the entry of cells by protein $S$ and the spread of the virus 
through the mucosa (Cornillez-Ty et al., 2009). Interestingly, it increases the nerve idling of the viral hepatitis virus (MHV) (Chatterjee et al., 2009); however, he chooses against tissue culture for unknown reasons (Egloff et al., 2006).

The ORF1a/b consists of about two-thirds of the viral genome and codes for 16 non-structural proteins as summarized in Table I. There is a shift in Box-1 between ORF1a and ORF1b, which results in the production of two peptides (pp1a and pplab), which are then processed by the viral coded protease at $16 \mathrm{nsp}$.

Table I. Function of non-structural protein of SARS-CoV-2s

\begin{tabular}{|c|c|c|}
\hline Protein & Function & References \\
\hline NSP 1 & $\begin{array}{l}\text { Promote cellular mRNA } \\
\text { degradation with the } \\
\text { translation of the host } \\
\text { cells prevent innate } \\
\text { immune response }\end{array}$ & $\begin{array}{l}\text { Eriksson et al., 2008; } \\
\text { Frieman et al., 2009 }\end{array}$ \\
\hline NSP 2 & $\begin{array}{l}\text { There is no known } \\
\text { function, linked to the } \\
\text { prohibition of proteins }\end{array}$ & $\begin{array}{l}\text { Serrano et al., 2009; } \\
\text { Ziebuhr et al., } 2001\end{array}$ \\
\hline NSP 3 & $\begin{array}{l}\text { Multidomain larger } \\
\text { transmembrane proteins } \\
\text { interact with activities } \\
\text { with protein N, promote } \\
\text { the expression of } \\
\text { cytokines, attach to the } \\
\text { viral protein, and block } \\
\text { the host's innate } \\
\text { immune response. }\end{array}$ & $\begin{array}{l}\text { Gadlage et al., 2010; } \\
\text { Oostra et al., 2008; } \\
\text { Egloff et al., } 2004\end{array}$ \\
\hline NSP 4 & $\begin{array}{lr}\text { Potential } & \text { membrane } \\
\text { scaffold } & \text { protein } \\
\text { responsible } & \text { for } \\
\text { providing } & \text { suitable } \\
\text { structure for DMVs }\end{array}$ & Xu et al., 2003 \\
\hline NSP 5 & $\begin{array}{l}\text { Mpro cleans viral } \\
\text { polyprotein }\end{array}$ & $\begin{array}{l}\text { Ivanov \& Ziebuhr, } \\
2004\end{array}$ \\
\hline NSP 6 & \begin{tabular}{ll} 
Potential & \multicolumn{2}{c}{ membrane } \\
scaffold protein & from \\
transliterating & viral \\
protein. &
\end{tabular} & Ivanov et al., 2004 \\
\hline NSP 7 & $\begin{array}{l}\text { The formation of a super } \\
\text { complex hexadecameric } \\
\text { with nsp8 could serve as }\end{array}$ & Eckerle et al., 2010 \\
\hline NSP 8 & $\begin{array}{l}\text { The formation of a super } \\
\text { complex hexadecameric } \\
\text { with nsp7 could serve as } \\
\text { a practical clamp for } \\
\text { RNA polymerase }\end{array}$ & Eckerle et al., 2007 \\
\hline NSP 9 & $\begin{array}{l}\text { Host-based } \\
\text { binding protein }\end{array}$ & Chen et al., 2019 \\
\hline NSP 10 & $\begin{array}{l}\text { The cofactor of nsp16 } \\
\text { and nsp14 forms } \\
\text { heterogeneous } \\
\text { modulator with both } \\
\text { and enhance Exon and } \\
\text { 2-O-MT activity }\end{array}$ & $\begin{array}{l}\text { Bhardwaj et al., } \\
2006\end{array}$ \\
\hline NSP 11 & $\begin{array}{l}\text { Cleavage of pp1a at the } \\
\text { NSP } 10 / 12 \text { junction }\end{array}$ & Decroly et al., 2008 \\
\hline
\end{tabular}

\begin{tabular}{|c|c|c|}
\hline NSP 12 & $\begin{array}{lr}\text { RNA-dependent } & \text { RNA } \\
\text { polymerase, } & \text { RdRp } \\
\text { (enzyme activity) } & \end{array}$ & Decroly et al., 2008 \\
\hline \multirow[t]{3}{*}{ NSP 13} & Nucleoside & Züst et al., 2011; \\
\hline & Triphosphatase & Cheng \& Shan, \\
\hline & $\begin{array}{ll}\text { (NTPase } & \text { enzyme) } \\
\text { activities } & \end{array}$ & 202 \\
\hline NSP 14 & $\begin{array}{l}\text { N7-MTase activities of } \\
\text { viral genomes }\end{array}$ & Chen et al., 2019 \\
\hline NSP 15 & $\begin{array}{l}\text { The major role of NSP } 15 \\
\text { in coronavirus } \\
\text { replication }\end{array}$ & $\begin{array}{l}\text { Bhardwaj et al., } \\
2004\end{array}$ \\
\hline NSP 16 & $\begin{array}{l}\text { 2'-O-MT (ribose 2'-O- } \\
\text { methyltransferase) } \\
\text { activity }\end{array}$ & Decroly et al., 2011 \\
\hline
\end{tabular}

\section{TRANSMISSION ROUTES OF SARS-CoV-} 2

The coronavirus first announced in December 2019 is now a public health emergency of international concern. Epidemiologists are working to update estimates the number of cases; genome samples of the pathogen are being sequenced and results are being shared (Zheng, 2020). Mechanisms of transmission are concluding to incorporate contact, droplet, and possibly airborne under certain circumstances supported on historical experiences associated with SARS-CoV outbreaks (Yu et al., 2020; Christian et al., 2004).

\section{Respiratory droplet}

Respiratory infection may be transmitted through droplets of varied sizes; when the droplet partials are smaller than 5-10 $\mu \mathrm{m}$ in diameter, they called respiratory droplets, and after they are smaller than $5 \mu \mathrm{m}$ in diameter they're called as droplet nuclei, per present evidence, COVID-19 virus is primarily transmitted between people through respiratory droplets and parson to parson close contact routes. Droplet spread occurs when an individual is in close contact (within a minute) with people who have respiratory symptoms (e.g. coughing or sneezing) and is therefore in danger of getting his/her mucosa (mouth and nose) or conjunctive (eyes) exposed to potentially infective respiratory droplets. Transmission can also occur through fomites with the immediate 
environment around the infected parson (Dbouk \& Drikakis, 2020).

\section{Focal-oral routes}

There is some evidence that COVID-19 infection may attend to intestinal infection and be present in fasces. However, thus for just one study has cultured the COVID-19 virus from one stool specimen (Zhang et al., 2020a). There are no announced of fecal-oral transmission of the COVID-19 virus thus for. The fundamental reproduction number (R0) for this infection, given variable host and environmental factors, is measurement within the initial outbreak to be between 2.2 and 3.6 (number of cases generated after exposure to at least one patient), which is said to SARS-CoV but on top of MERSCoV (Zhao et al., 2020).

People who live or travel a lot in Hubei province are at risk of infection. Also, doctors and health officials who are infected to new coronavirus patients have a good chance of contracting the virus, despite appropriate preventive measures. One of the first signs of transmission between people is health care providers who develop the disease.

\section{PATHOGENESIS OF COVID-19}

The pathogenesis of COVID-19 infection is mostly related to the depletion of type 2 respiratory pneumocyte cells resulting in profound alveoli destruction as visualized in Figure 5.

\section{Selective tropism for pneumocyte molecular receptor}

The first coronavirus receptors were identified by the MHV receptor as listed in Table II. The MHV binds to the Murine carcinoembryonic antigens related adhesion molecule 1 (mCEACAM1) adhesion molecule (the adhesion molecule of membranous cancer cell antigen) to cell injury. The mCEACAM1 can be a type I membrane protein linked to the immunoglobulin superfamily. The mCEACAM1 can be a multifunctional protein that has manic roles in cell adhesion and signaling, among other things. Ectodomain of mCEACAM1 has four established causes of IgM such as domains, N, A1, B, and A2. The mCEACAM1's N-terminal $\mathrm{N}$ field shares the MHV connection (Belouzard et al., 2012).

The intervention of the virus at the site of binding of receptors

The entry of the encapsulated virus may occur directly on the cell surface after attachment to the receptor or after its absorption by the multiplication of cells with fusion in the endosomal chamber. The fusion of viral membranes with the host membranes occurs due to the large corresponding changes in the peak of the protein. Over time, coronaviruses modified their climax of proteins, resulting in a group of catalysts that would not activate their fusion. These matching changes will begin by binding to the receptor but may have additional catalysts such as $\mathrm{pH}$ acidification or protein activation (Cheng et al., 2004).

Table II. Different types of receptors proteins presence of different coronavirus species

\begin{tabular}{|c|c|c|c|}
\hline $\begin{array}{l}\text { Classes } \\
\text { of Virus }\end{array}$ & Species & Receptor & References \\
\hline \multirow[t]{6}{*}{$\mathrm{a}-\mathrm{CoV}$} & TGEV & $\begin{array}{l}\text { Aminopeptidase } \\
\mathrm{N}(\mathrm{APN})\end{array}$ & $\begin{array}{l}\text { Delmas et al., } \\
1992\end{array}$ \\
\hline & $\mathrm{CCoV}$ & $\mathrm{APN}$ & $\begin{array}{l}\text { Benbacer et } \\
\text { al., } 1997\end{array}$ \\
\hline & $\mathrm{FeCoV}$ & $\mathrm{APN}$ & $\begin{array}{l}\text { Tresnan et al., } \\
1996\end{array}$ \\
\hline & PEDV & $\mathrm{APN}$ & Li et al., 2007 \\
\hline & $\begin{array}{l}\text { HCoV- } \\
229 \mathrm{E}\end{array}$ & $\mathrm{APN}$ & $\begin{array}{l}\text { Yeager et al., } \\
1992\end{array}$ \\
\hline & $\begin{array}{l}\mathrm{HCoV}- \\
\text { NL63 }\end{array}$ & $\begin{array}{l}\text { Angiotensin- } \\
\text { converting } \\
\text { enzyme } 2 \text { (ACE2) }\end{array}$ & $\begin{array}{l}\text { Hofmann et } \\
\text { al., } 2005\end{array}$ \\
\hline \multirow[t]{6}{*}{$\beta-\mathrm{CoV}$} & $\mathrm{BCoV}$ & $\begin{array}{l}\mathrm{N} \text {-acetyl-9-O- } \\
\text { acetylneuraminic } \\
\text { acid }\end{array}$ & $\begin{array}{l}\text { Schultze \& } \\
\text { Herrler, } 1992\end{array}$ \\
\hline & MHV & $\begin{array}{l}\text { Murine } \\
\text { carcinoembryonic }\end{array}$ & $\begin{array}{l}\text { Nedellec et } \\
\text { al., 1994; }\end{array}$ \\
\hline & & $\begin{array}{l}\text { antigens related } \\
\text { adhesion }\end{array}$ & $\begin{array}{l}\text { Williams et } \\
\text { al., } 1991\end{array}$ \\
\hline & & $\begin{array}{ll}\text { molecule } & 1 \\
(\mathrm{mCEACAM}) & \end{array}$ & \\
\hline & $\begin{array}{l}\text { SARS- } \\
\text { CoV }\end{array}$ & ACE2 & Li et al., 2003 \\
\hline & $\begin{array}{l}\text { MERS- } \\
\mathrm{CoV}\end{array}$ & $\begin{array}{l}\text { Dipeptidyl } \\
\text { peptidase } \\
\text { (DPP4) }\end{array}$ & Raj et al., 2013 \\
\hline
\end{tabular}




\section{Integration of viral DNA into the host cell}

The primary association of virion with the hostcell begins with interactions between protein $\mathrm{S}$ and its receptor. Recipient binding domain (RBD) sites within the $\mathrm{S1}$ protein $\mathrm{S}$ site of the coronavirus vary depending on the virus, some have RBD at the end $\mathrm{N}$ of $\mathrm{S1}(\mathrm{MHV})$, while others SARS-CoV have an RBD at the C term of S1 (Krijnse-Locker et al., 1994). The interaction of $S$ protein receptors is the primary determinant of coronaviruses to infect host species and also leads to polarization of the virus tissue. SARS-CoV and HCoV-NL63 use the ACE2 as a receptor, enter the MHV via MCEACAM1, and connect the newly identified MERS-CoV with dipeptidyl peptidase 4 (DPP4) to enter human cells as presented in

Table II.

\section{Repetition}

The next step in the life cycle of a coronavirus is to translate the mimic gene from the viral genomic RNA.
The gene codes for two large ORFs, rep1a and rep1b, which connect to two homogeneous polypropylene proteins, pp1a and pplab. To deliver multiple proteins, the virus uses a sliding sequence (5'-UUUAAAC-3') and RNA pseudoknot that causes the displacement of the ribosome frame from the rep1a reading frame towards the ORF rep1b. In most cases, the ribosome breaks down the pseudoknot structure and extends the translation until it satisfies colonic stop code 1 . Sometimes, the false node prevents the ribosome from continuing to elongate, resulting in a temporary stop in the slippery sequence, adjusting the reading frame by moving the nucleotide, and turning- 1 frame before the ribosome can dissolve the pseudoknot structure and extend the translation to rep1b, which leads to an interpretation of pp1ab (Cheng \&Shan, 2020; Yu et al., 2004).

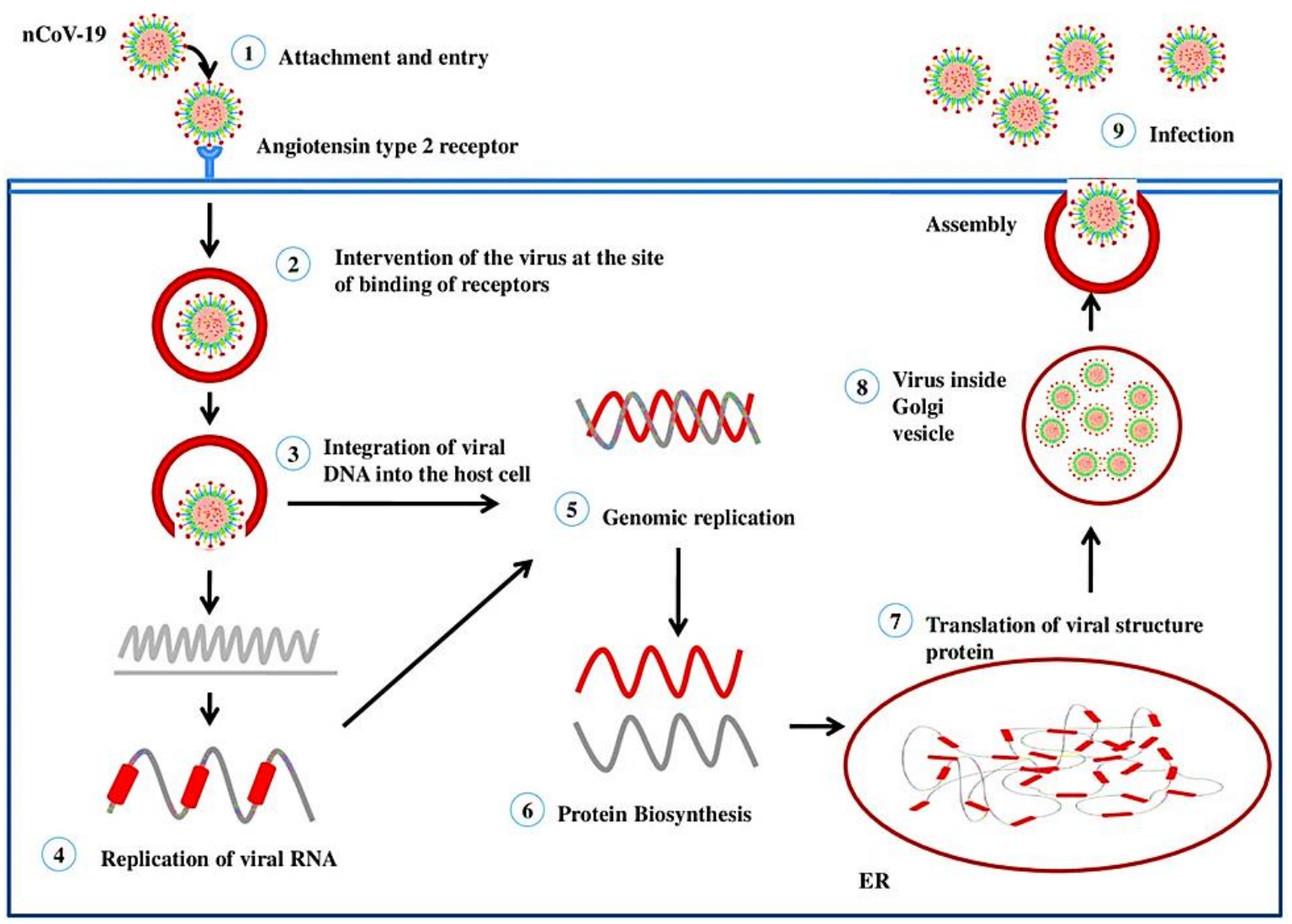

Figure 5. Replication process of SARS-CoV-2 


\section{Destruction of type 2 respiratory pneumocyte cell}

Viral particles transcribed into the respiratory type 2 lung cell begin to form buds forming the cell wall of the host cell. When these particles separate from the affected host cell, they damage part of the cell membrane of the host cell and cause the host cell to die by programmed cell death.

\section{Viral spread}

After reproduction and synthesis of RNA without genome, viral structural proteins $\mathrm{S}, \mathrm{E}$, and $\mathrm{M}$ are translated and inserted into the endoplasmic reticulum (ER). These proteins travel along the secretory pathway in the endoplasmic reticulum - Golgi compartment (ERGIC) (Tooze et al., 1984; de Haan \& Rottier, 2005). There, viral genomes coated with $\mathrm{N}$ protein in ERGIC membranes contain viral structural proteins, forming mature virions (Arons et al., 2020).

\section{SYMPTOMS OF COVID-19}

The maximum number of patients infected with the virus will suffer from colds and influenza, while a few will remain asymptomatic. About $80 \%$ of patients will experience mild symptoms of the disease. Adults have the best immunity to fight infection, but the disadvantage is that they are more likely to spread infection and a recent study of nearly 140 patients at Zhong nan Hospital of Wuhan University has revealed two different. Types of symptoms that lead to a disease known as COVID-19. Almost $99 \%$ of the patients developed a very hot fever, while more than half of them experienced fatigue and a dry cough. A third of the patients developed a dry cough and difficulty breathing (Yi et al., 2020; Fu et al., 2020).

\section{DIAGNOSIS OF COVID-19}

The diagnosis allows suspects to understand whether they are infected or not. Diagnosis can help get the care they need and can help them take steps to reduce the likelihood of injury to others. If a person develops symptoms of coronavirus 2019 and is exposed to the virus, he consults a doctor. The doctor can decide whether or not to test COVID-19 based on individual signs and symptoms. The doctor can also determine if the person is in close contact with a person diagnosed with COVID-19 or who has visited or lived in areas where the community has continued to spread COVID-19 in the past 14 days (Jin et al., 2020).

\section{Direct detection}

The SARS-CoV-2 infection is detected by special laboratory tests that require samples such as throat swabs or lung fluid. This method is called a PCR test and it takes 24 to 48 hours to get the final results. WHO recommends sampling the upper and lower respiratory tract. This can be done with sputum, bronchial lavage, or end-trachea sucking. These samples will then determine the viral RNA identity using a polymerase chain reaction (PCR). If a positive test result is obtained, it is recommended to repeat the activation test. Negative tests with strong clinical suspicion are also recommended for repeated testing (Kumar et al., 2020; Hassan et al., 2020).

\section{Serological test}

The SARS-CoV ELISA and IgM ELISA Inner control kits were developed using IDR 3 N SARS-CoV as antigens, which share $90 \%$ amino acid alkene identity with all or all SARSr-CoVs2. For IgG analysis, the 96-well MaxiSorp Nunc-Immuno ELISA sheet (100 ng per well) was coated overnight with recombinant $\mathrm{N}$ protein. Human sera are used at 1:20 dilution for one hour at $37^{\circ} \mathrm{C}$. Monoclonal antibody IgG HRP (Kyab Biotech) was used at a dilution of $1: 40000$. OD value (calculated 450-630 nm). For IgM analysis, the 96-well MaxiSorp Nunc-Immuno ELISA sheet (500 ng per well) was coated overnight using antihuman IgM ( $\mu$ series). Human sera are used at $1: 100$ dilutions for 40 minutes at $37^{\circ} \mathrm{C}$, and then incubated with 
anti-Rp. 3 N HRP (Kyab Biotech) antibodies at 1: 4,000 dilutions. OD values (450) - $630 \mathrm{~nm}$ ) are calculated (Okba et al., 2020).

\section{RNA vaccines}

Modern Biotechnology Company in Cambridge has prepared a test vaccine for coronavirus diagnosis. This rapid change is due to the unique advantages of RNA vaccines, says MIT Professor Daniel Anderson that the main advantage of the RNA message is the speed with which you can define and use a new sequence to find a new vaccine (World Health Organization, 2020).

\section{Molecular examinations}

Currently, many of the tests that reveal SARS-CoV-2 are prepared internally, commercially, or under development. Some tests can only detect the new virus, and some tests can also detect other strains that are genetically similar (Trafton et al., 2020).

\section{TREATMENT OF COVID-19}

Currently, there is no specific treatment, vaccine, or drug for the virus. However, healthcare professionals have many ways to help patients. First, early diagnosis helps stop the spread of the disease, making society a safer place for everyday life. Second, there are supportive care options that seem to work miracles with new coronavirus patients.

\section{General treatment}

A confirmed COVID-19 patient needs complete bed rest and supportive treatment, ensuring that enough calories and fluids are consumed to reduce the risk of dehydration. Water and homeostasis must be maintained while monitoring vital signs and oxygen saturation; keep the airways clean and inhale the oxygen in more severe cases; Measure blood count, creative protein, urine test and other biochemical blood clues, including liver and kidney functions, group of heart muscle enzymes, and clotting function depending on patient conditions. Chest imaging should be reviewed continuously, and blood gas should be analyzed if necessary (Zhejiang University School of Medicine, 2020).

\section{Symptomatic treatment}

Control measures are needed for patients with a high fever. Antipyretic treatment should be done if the temperature exceeds $38.5^{\circ} \mathrm{C}$. Warm baths and antipyretic stains are preferred as a precautionary measure to reduce the temperature. Common medications include oral ibuprofen, 5-10 mg/kg each; Oral acetaminophen, 10 to $15 \mathrm{mg} / \mathrm{kg}$ at a time (Zhejiang University School of Medicine, 2020).

\section{Oxygen therapy}

The risk of hypoxia increases when the virus targets the lungs. A nasal catheter and an oxygen mask should be provided to the patient immediately. In an emergency, non-invasive or invasive mechanical ventilation should be provided to the patient (Shen et al., 2020).

\section{Antiviral drugs}

Various antiviral drugs, including interferon-alpha (IFNa), lopinavir/ritonavir, chloroquine phosphate, ribavirin, and arbidol are therapeutically useful for the prevention, diagnosis, and treatment of new induced pneumonia by SARS-CoV-2 by the National Health Committee (CNS) of the People's Republic of China For the temporary treatment of COVID-19. IFN- $\alpha$ is a widespread antiviral that is usually used to treat hepatitis, although it has been reported to prevent SARS reproduction in $\mathrm{CoV}$ in vitro. IFN-a is given as a vapor twice a day. Fifth editions of the guidelines approved antiviral drugs including IFN-a, lopinavir/ritonavir, and ribavirin for the treatment of COVID-19. Chloroquine is incorporated in the sixth version of the guidelines based on preliminary results of clinical studies. The specific method for administering IFN- $a$ is the inhalation of vapor at a dose of 5 million units 
(and $2 \mathrm{ml}$ of sterile water for injection) for adults, twice a day. The dose of lopinavir/ritonavir is $400 \mathrm{mg} / 100 \mathrm{mg}$ for adults, twice daily. Ribavirin should be administered by intravenous infusion at a dose of $500 \mathrm{mg}$ for adults, 23 times/day in combination with IFN-a or lopinavir/ritonavir. Oral chloroquine phosphate is administered in a dose of $500 \mathrm{mg}$ ( $300 \mathrm{mg}$ of chloroquine) for adults, twice a day. Arbidol is given orally at a dosage of $200 \mathrm{mg}$ for adults, three times/day. The duration of treatment does not exceed 10 days (Zhang et al., 2020b; Wu et al., 2020b).

Favipiravir is a new drug in clinical trials for the treatment of COVID-19. On February 15 ${ }^{\text {th }}, 2020$, China agreed that it was a useful drug for treating the new flu. It works by inhibiting the enzyme-dependent RNA polymerase RNA. Favipiravir is transformed into an active phosphorylate (favipiravir-RTP) form in cells and is recognized as a substrate by viral RNA polymerase, thereby inhibiting the activity of RNA polymerase. Therefore, favipiravir may have a potent antiviral effect on SARS-CoV-2, which is the RNA virus (Yavuz \& Unal, 2020).

Remdesivir is another investigative drug in the clinical trial for the treatment of COVID-19. Remdesivir is a broad-spectrum nucleoside and antiviral analog. Animal experiments have indicated that remdesivir can effectively reduce viral load in lung tissue in mice infected with MERS-CoV virus, improve lung function and reduce pathological damage to lung tissue ( $\mathrm{Wu}$ et al., 2020b; Cao et al., 2020).

A team of researchers from the Shanghai Materia Medica Institute and the Shanghai University of Technology conducted silicon drugs and enzyme activity testing and reported 30 workers who might have antiviral activity against SARS-CoV-2 on January $25^{\text {th }}, 2020$. These factors are indinavir, saquinavir, lopinavir, Carfilzomib, ritonavir, remdesivir, atazanavir, darunavir, tipranavir, fosamprenavir, enzaplatovir, presatovir, abacavir, bortezomib, cyclosporine $\mathrm{A}$ and cinanserin. It has also been proven that some Chinese herbal medicines such as Rhizoma Polygoni Cuspidati and Radix Sophorae Tonkinensis contain certain active ingredients that were effective against COV-2 (Shen et al., 2020).

\section{Antibiotic drugs}

The third class of medicinal drugs is Azithromycin, a class of antibiotics known as macrolide that is used to treat infections such as bronchitis, pneumonia, and MAC infection (Mycobacterium avium complex). With the spread of SARS-CoV-2, many countries around the world have started developing countermeasures to limit the spread of the disease. The authors found that in addition to hydroxychloroquine, another FDA-approved drug known as Azithromycin had therapeutic effects against COVID-19 in a study accompanied by a University of New Mexico research group (Choudhary \& Sharma, 2020).

\section{Anti-coagulating therapy}

Hospital patients with severe medical illness are at an increased risk of developing VTE up to 90 days after discharge. This result should apply to COVID-19 patients, although infection data don't seem to be yet available. Therefore, it is reasonable to think of long blood clots occurring after prolonged discharge using a regulated approved system (such as betrixaban $160 \mathrm{mg}$ on the first day, followed by $80 \mathrm{mg}$ once daily for 35 to 42 days; or rivaroxaban $10 \mathrm{mg}$ daily for 31 to 39 Days) (Porfidia \& Pola, 2020).

\section{Boosts the immune system}

In addition to basic disease prevention and true defense, there is a strong immune system. The human body is better able to fight disease when the immune system is impulsive and people have to get fit to get the perfect shape. In this critical condition, get enough sleep and a little fresh air and the sun every day. People also need to 
stay hydrated, reduce excessively processed foods, and make sure to eat enough micronutrients when they can do their best with what they can find in grocery stores right now (Taghizadeh-Hesary \& Akbari, 2020).

\section{PREVENTION AND CONTROL OF COVID-19}

This new virus often features a limited geographic spread (Zappa et al., 2009). However, there are the amounts of hygiene measures that are recommended to guard against the infection and for the spread the include following advisory are covering your mouth and nose with masks, avoiding close contact with those that are sick, stop shaking hand with one other, washing hands regularly after one hour with soap, avoiding unnecessary contact with animals and hand washing, use of masks and PPE (Personal protective equipment), drinking warm water daily, sanitize your hands time to time (Singhal, 2020).

\section{Steps to protect yourself}

1. Wash your hands regularly and completely with soap and water for at least 20 seconds or with an alcohol-based hand sanitizer (a hand sanitizer that contains at least $60 \%$ alcohol), rub the cover thoroughly together so that it does not dry out, especially after visiting a public place, or after blowing your nose or sneeze as well as cough.

2. Hands touch many surfaces and catch viruses, and these contaminated hands can spread the virus to your nose, eyes, or mouth. So, avoid touching these organs with unwashed hands. Because from there, the virus can enter the body and make people sick.

3. Maintain a social distance (keep at least $1 \mathrm{~m}$ or 3 feet between you and anyone) and avoid close contact with patients (who cough or sneeze). When infected or sneeze, they spray small drops from their nose or mouth that may contain the COVID-19 virus. A person can breathe these drops (Centers for Disease Control and Prevention, 2020).

\section{Steps to protect others}

1. Stay home if you are not feeling well unless you will get medical treatment.

2. If you have a cough, fever, and difficulty breathing, see your doctor online, see your doctor.

3. If you are sick, avoid using public transportation.

4. When you cough or sneeze, cover your mouth and nose with a tissue.

5. Throw used tissue into the trash and wash your hands immediately with cleansing water and soap.

6. If possible, stay isolated in a room separate from family and pets and wear a face mask when you are with other people (for example, sharing a room or car). If you are unable to wear a face mask (for reasons related to breathing difficulties or for any other reason), you cover coughs and sneezes, but when people caring for you enter your room they should wear a face mask (face masks may be low in width and should be kept for caregivers).

7. Stay home for some time and follow your doctor's instructions.

8. If you are sick, avoid sharing bedding, dishes, glasses, and other household items.

9. Use a separate bathroom and toilet, if possible.

10. If the surfaces are dirty, clean them and use detergents or antiseptic soaps and water before using the disinfectant,

11. Apply antiseptic daily to frequently affected surfaces. This includes offices, telephones, keyboards, toilets, faucets, tables, door handles, lighting switches, counters, knobs, and basins.

12. Identify and isolate suspected cases.

13. Before starting clinical care, identify potential cases as soon as possible and isolate suspects separately from those who have confirmed cases of COVID-19, to 
prevent the possible transmission of infection to other patients and nursing staff.

14. Avoid direct physical contact (including physical examination and exposure) to other respiratory and physical secretions. For example, move the possibility of infectious people into isolation rooms and close the doors. In the workplace, make the distance between workers, clients, and other visitors, especially from the location of potentially infectious people.

15. If there is a need to isolate a patient or a group of patients, pharmacies must determine and prepare an appropriate space.

16. Most patients coming to community pharmacies are unlikely to have COVID-19. If you have symptoms of a cough, cold, or flu-like symptoms, but not related to COVID-19, or the date of travel or contact, pharmacies should do so following their best practices and routine infection risk management. Across to other employees and patients.

17. Restrict the number of individuals entering isolation areas, including the bedroom of a patient with suspected and confirmed COVID-19.

18. To practice safe work, protect workers from close contact with the affected person using additional technical and administrative controls (Occupational Safety and Health Administration, 2020).

\section{CONCLUSION}

The COVID-19 pandemic is traveling around the world at a dangerous rate. More infections and deaths are caused by SARS or ME respiratory syndrome. The R0 values supported, SARS-CoV-2 assumed more SARS or MERS infection. The elderly and HIV-positive patients are at greater risk of death. The first outbreak requires extensive surveillance and isolation protocols to stop transmission. No confirmed drugs or vaccines were developed. The first treatment strategies are aimed at symptomatic care and oxygen therapy. Preventive vaccination is necessary for the long-term prevention of epidemics or epidemics associated with the coronavirus.

\section{ACKNOWLEDGMENT}

The authors would like to express our deep gratitude to all those who helped us directly and indirectly in the realization of the work of this review article.

\section{REFERENCES}

Adhikari, S.P., Meng, S., Wu, Y.J., Mao, Y.P., Ye, R.X., Wang, Q.Z., Sun, C., Sylvia, S., Rozelle, S., Raat, H., \& Zhou, H. (2020). Epidemiology, causes, clinical manifestation and diagnosis, prevention, and control of coronavirus disease (COVID-19) during the early outbreak period: a scoping review. Infectious Diseases of Poverty, 9, 9. doi:10.1186/s40249-020-00646-x

Arons, M.M., Hatfield, K.M., \& Tanwar, S. (2020). Presymptomatic SARS-CoV-2 infections and transmission in a skilled nursing facility. The New England Journal of Medicine, 382(22),20812090. doi:10.1056/NEJMoa2008457

Bárcena, M., Oostergetel, G.T., Bartelink, W., Faas, F.G.A., Verkleij, A., Rottier, P.J.M., Koster, A.J., \& Bosch, B.J. (2009). Cryo-electron tomography of mouse hepatitis virus: insights into the structure of the coronavirion. Proceedings of the National Academy of Sciences of the United States of America, 106(2), 582-587. doi:10.1073/pnas.0805270106

Belouzard, S., Millet, J.K., Licitra, B.N., \& Whittaker, G.R. (2012). Mechanisms of Coronavirus Cell Entry Mediated by the Viral Spike Protein. Viruses, 4(6), 1011-1033. doi:10.3390/v4061011

Benbacer, L., Kut, E., Besnardeau, L., Laude, H., \& Delmas, B. (1997). Interspecies aminopeptidase-N Chimeras Reveal SpeciesSpecific Receptor Recognition by Canine Coronavirus, Feline Infectious Peritonitis Virus, and Transmissible Gastroenteritis Virus. Journal of Virology, 71(1), 734-737.

Bhardwaj, K., Guarino, L., \& Kao, C.C. (2004). The Severe Acute Respiratory Syndrome Coronavirus Nsp15 Protein Is an Endoribonuclease That 
Prefers Manganese as a Cofactor. Journal of Virology, $\quad$ 78(22), $\quad$ 12218-12224. doi:10.1128/jvi.78.22.12218-12224.2004

Bhardwaj, K., Sun, J., Holzenburg, A., Guarino, L.A., \& Kao, C.C. (2006). RNA Recognition and Cleavage by the SARS Coronavirus Endoribonuclease. Journal of Molecular Biology, 361(2), 243-256. doi:10.1016/j.jmb.2006.06.021

Cao, Y.C., Deng, Q.X., \& Dai, S.X. (2020). Remdesivir for severe acute respiratory syndrome coronavirus 2 causing COVID-19: An evaluation of the evidence. Travel Medicine and Infectious Disease, [Epub ahead of print], 101647. doi:10.1016/j.tmaid.2020.101647

Centers for Disease Control and Prevention. (2020). What you should know about COVID-19 to protect yourself and others. https://www.cdc.gov/coronavirus/2019ncov/downloads/2019-ncov-factsheet.pdf

Chatterjee, A., Johnson, M.A., Serrano, P., Pedrini, B., Joseph, J.S., Neuman, B.W., Saikatendu, K., Buchmeier, M.J., Kuhn, P., \& Wüthrich, K. (2009). Nuclear Magnetic Resonance Structure Shows That the Severe Acute Respiratory Syndrome Coronavirus-Unique Domain Contains a Macrodomain Fold. Journal of Virology, $\quad 83(4), \quad$ 1823-1836. doi:10.1128/jvi.01781-08

Chen, S., Liu, D., Tian, J., Kang, H., Guo, D., Jiang, Q., Liu, J., Li, Z., Hu, X., \& Qu, L. (2019). Molecular characterization of HLJ-073, a recombinant canine coronavirus strain from China with an ORF3abc deletion. Archives of Virology, 164(8), 2159-2164. doi:10.1007/s00705-019-04296-9

Chen, Z.M., Fu, J.F., Shu, Q., Chen, Y.H., Hua, C.Z., Li, F.B., Lin, R., Tang, L.F., Wang, T.L., Wang, W., Wang, Y.S., Xu, W.Z., Yang, Z.H., Ye, S., Yuan, T.M., Zhang, C.M., \& Zhang, Y.Y. (2020). Diagnosis and Treatment Recommendations for Pediatric Respiratory Infection Caused by the 2019 Novel Coronavirus. World Journal of Pediatrics, 1-7. doi:10.1007/s12519-020-00345-5

Cheng, Z.J. \& Shan, J. (2020). 2019 Novel coronavirus: where we are and what we know. Infection, 48, 155-163. doi:10.1007/s15010-020-01401-y

Cheng, P.K., Wong, D.A., Tong, L.K., Ip, S.M., Lo, A.C.T., Lau, C.S., Yeung, E.Y.H., \& Lim, W.W.L. (2004). Viral Shedding Patterns of Coronavirus in Patients with Probable Severe Acute Respiratory Syndrome. The Lancet, 363(9422), 1699-1700. doi:10.1016/s0140-6736(04)16255-7

Choudhary, R. \& Sharma, A.K. (2020). Potential use of hydroxychloroquine, ivermectin and azithromycin drugs in fighting COVID-19: trends, scope and relevance. New Microbes and New Infections, 35, 100684. doi:10.1016/j.nmni.2020.100684

Christian, M.D., Loutfy, M., McDonald, L.C., Martinez, K.F., Ofner, M., Wong, T., Wallington, T., Gold, W.L., Mederski, B., Green, K., \& Low, D.E. (2004). Possible SARS Coronavirus Transmission during Cardiopulmonary Resuscitation. Emerging infectious diseases, 10(2), 287-293. doi:10.3201/eid1002.030700

Cornillez-Ty, C.T., Liao, L., Yates, J.R., Kuhn, P., \& Buchmeier, M.J. (2009). Severe Acute Respiratory Syndrome Coronavirus Nonstructural Protein 2 Interacts with a Host Protein Complex Involved in Mitochondrial Biogenesis and Intracellular Signaling. Journal of Virology, 83(19), 10314-10318. doi:10.1128/jvi.00842-09

Dbouk, T. \& Drikakis, D. (2020). On coughing and airborne droplet transmission to humans. Physics of Fluids, 32, 053310. doi:10.1063/5.0011960

Decroly, E., Debarnot, C., Ferron, F., Bouvet, M., Coutard, B., Imbert, I., Gluais, L., Papageorgiou, N., Sharff, A., Bricogne, G., Ortiz-Lombardia, M., Lescar, J., \& Canard, B. (2011). Crystal Structure and Functional Analysis of the SARScoronavirus RNA Cap 2'-O-methyltransferase nsp10/nsp16 Complex. PLoS Pathogens, 7(5), e1002059. doi:10.1371/journal.ppat.1002059

Decroly, E., Imbert, I., Coutard, B., Bouvet, M., Selisko, B., Alvarez, K., Gorbalenya, A.E., Snijder, E.J., \& Canard, B. (2008). Coronavirus Nonstructural Protein 16 Is a Cap-0 Binding Enzyme Possessing (Nucleoside-2'O)Methyltransferase Activity. Journal of Virology, 82(16), 8071-8084. doi:10.1128/jvi.00407-08

Delmas, B., Gelfi, J., L'Haridon, R., Vogel, L.K., Sjoestoem, H., Noren, O., \& Laude, H. (1992). Aminopeptidase N Is a Major Receptor for the Entero-Pathogenic Coronavirus TGEV. Nature, $\quad 357(6377), \quad 417-420$. doi:10.1038/357417a0 
Dhama, K., Pawaiya, R.V.S., Chakraborty, S., Tiwari, R., Saminathan, M., \& Verma, A.K. (2014). Coronavirus infection in equines: A review. Asian Journal of Animal and Veterinary Advances, 9(3), 164-176. doi:10.3923/ajava.2014.164.176

Drosten, C., Gunther, S., Preiser, W., van der Werf, S., Brodt, R., Berger, S., Panning, M., Kolesnikova, L., Eickmann, M., Escriou, N., Grywna, K., Kramme, S., Manuguerra, C., Muller, S., Rickerts, V., Sturmer, M., Vieth, S., Klenk, H.D., Osterhaus, A.D.M.E., Schmitz, H., \& Doerr, H.W. (2003). Identification of a Novel Coronavirus in Patients with Severe Acute Respiratory Syndrome. The New England Journal of Medicine, 348(20), 1967-1976. doi:10.1056/nejmoa030747

Eckerle, L.D., Becker, M.M., Halpin, R.A., Li, K., Venter, E., Lu, X., Scherbakova, S., Graham, R.L., Baric, R.S., Stockwell, T.B., Spiro, D.J., \& Denison, M.R. (2010). Infidelity of SARS-CoV Nsp14exonuclease Mutant Virus Replication Is Revealed by Complete Genome Sequencing. PLoS Pathogens, 6(5), e1000896. doi:10.1371/journal.ppat.1000896

Eckerle, L.D., Lu, X., Sperry, S.M., Choi, L., \& Denison, M.R. (2007). High Fidelity of Murine Hepatitis Virus Replication Is Decreased in nsp14 Exoribonuclease Mutants. Journal of Virology, 81(22), 12135-12144. doi:10.1128/jvi.01296-07

Egloff, M.P., Ferron, F., Campanacci, V., Longhi, S., Rancurel, C., Dutarte, H., Snijder, E.J., Gorbalenya, A.E., Cambilau, C., \& Canard, B. (2004). The Severe Acute Respiratory Syndrome-Coronavirus Replicative Protein nsp9 Is a Single-Stranded RNA-binding Subunit Unique in the RNA Virus World. Proceedings of the National Academy of Sciences of the United States of America, 101(11), 3792-3796. doi:10.1073/pnas.0307877101

Egloff, M.P., Malet, H., Putics A., Heinonen, M., Dutarte, H., Frangeul, A., Gruez, A., Campanacci, V., Cambillau, C., Ziebuhr, J., Ahola, T., \& Canard, B. (2006). Structural and Functional Basis for ADP-Ribose and Poly(ADP-Ribose) Binding by Viral Macro Domains. Journal of Virology, 80(17), 8493-8502. doi:10.1128/JVI.00713-06

Eriksson, K.K., Cervantes-Barragán, L., Ludewig, B., \& Thiel, V. (2008). Mouse Hepatitis Virus Liver Pathology Is Dependent on ADP-ribose-1"phosphatase, a Viral Function Conserved in the Alpha-LikeSupergroup. Journal of Virology, 82(24), 12325-12334. doi:10.1128/jvi.02082-08

Fan, Y., Zhao, K., Shi, Z.L., \& Zhou, P. (2019). Bat Coronaviruses in China. Viruses, 11(3), 210. doi:10.3390/v11030210

Frieman, M., Ratia, K., Johnston, R.E., Mesecar, A.D., \& Baric, R.S. (2009). Severe Acute Respiratory Syndrome Coronavirus Papain-Like Protease Ubiquitin-Like Domain and Catalytic Domain Regulate Antagonism of IRF3 and NF-kappaB Signaling. Journal of Virology, 83(13), 6689-6705. doi:10.1128/jvi.02220-08

Fu, L., Wang, B., Yuan, T., Chen, X., Ao, Y., Fitzpatrick, T., Li, P., Zhou, Y., Lin, Y.F., Duan, Q., Luo, G., Fan, S., Lu, Y., Feng, A., Zhan, Y., Liang, B., Cai, W., Zhang, L., Du, X., Li, L., Shu, Y., \& Zou, H. (2020). Clinical characteristics of coronavirus disease 2019 (COVID-19) in China: A systematic review and meta-analysis. Journal of Infection, $\quad 80(6), \quad 656-665$. doi:10.1016/j.jinf.2020.03.041

Gadlage, M.J., Sparks, J.S., Beachboard, D.C., Cox, R.G., Doyle, J.D., Stobart, C.C., \& Denison, M.R. (2010). Murine Hepatitis Virus Nonstructural Protein 4 Regulates Virus-Induced Membrane Modifications and Replication Complex Function. Journal of Virology, 84(1), 280-290. doi:10.1128/jvi.01772-09

Graham, R.L., Sims, A.C., Brockway, S.M., Baric, R.S., \& Denison, M.R. (2005). The nsp2 replicase proteins of murine hepatitis virus and severe acute respiratory syndrome coronavirus are dispensable for viral replication. Journal of Virology, $\quad 79(21), \quad$ 13399-13411. doi:10.1128/jvi.79.21.13399-13411.2005

Guo, Y.R., Cao, Q.D., Hong, Z.S., Tan, Y.Y., Chen S.D., Jin, H.J., Tan, K.S., Wang, D.Y., \& Yan, Y. (2020). The origin, transmission and clinical therapies on coronavirus disease 2019 (COVID-19) outbreak - an update on the status. Military Medical Research, 7, 11. doi:10.1186/s40779-02000240-0

de Haan, C.A.M. \& Rottier, P.J.M. (2005). Molecular Interactions in the Assembly of Coronaviruses. Advances in Virus Research, 64, 165-230. doi:10.1016/s0065-3527(05)64006-7

Hafeez, A., Ahmad, S., Siddqui, S.A., Ahmad, M., \& Mishra, S. (2020). A Review of COVID-19 
(Coronavirus Disease-2019) Diagnosis, Treatments and Prevention. Eurasian Journal of Medical Sciences and Oncology, 4(2), 116-125. doi:10.14744/ejmo.2020.90853

Hassan, S.A., Sheikh, F.N., Jamal, S., Ezeh, J.K., \& Akhtar, A. (2020). Coronavirus (COVID-19): A Review of Clinical Features, Diagnosis, and Treatment. Cureus, 12(3), e7355. doi:10.7759/cureus.7355

Hofmann, H., Pyrc, K., van der Hoek, L., Geier, M., Berkhout, B., \& Pöhlmann, S. (2005). Human Coronavirus NL63 Employs the Severe Acute Respiratory Syndrome Coronavirus Receptor for Cellular Entry. Proceedings of the National Academy of Sciences of the United States of America, 102(22), 7988-7993. doi:10.1073/pnas.0409465102

Hui, D.S., Azhar, I.E., Madani, T.A., Ntoumi, F., Kock, R., Dar, O., Ippolito, G., Mchugh, T.D., Memish, Z.A., Drosten, C., Zumla, A., \& Petersen, E. (2020). The Continuing 2019-nCoV Epidemic Threat of Novel Coronaviruses to Global Health - The Latest 2019 Novel Coronavirus Outbreak in Wuhan, China. International Journal of Infectious Diseases, 91, 264-266. doi:10.1016/j.jiji.2020.01.009

Hurst, K.R., Koetzner, C.A., \& Masters, P.S. (2013). C Characterization of a Critical Interaction between the Coronavirus Nucleocapsid Protein and Nonstructural Protein 3 of the Viral Replicase-Transcriptase Complex. Journal of virology, 87(16), 9159-9172. doi:10.1128/JVI.01275-13

Ivanov, K.A. \& Ziebuhr, J. (2004). Human Coronavirus 229E Nonstructural Protein 13: Characterization of Duplex-Unwinding, Nucleoside Triphosphatase, and RNA 5'Triphosphatase Activities. Journal of Virology, 78(14), 7833-7838. doi:10.1128/JVI.78.14.78337838.2004

Ivanov, K.A., Thiel, V., Dobbe, J.C., van der Meer, Y., Snijder, E.J., \& Ziebuhr, J. (2004). Multiple Enzymatic Activities Associated with Severe Acute Respiratory Syndrome Coronavirus Helicase. Journal of Virology, 78(11), 5619-5632. doi:10.1128/jvi.78.11.5619-5632.2004

Ji, W., Wang, W., Zhao, X., Zai, J., \& Li, X. (2020). Crossspecies transmission of the newly identified coronavirus 2019-nCoV. Journal of Medical Virology, 92(4), 433-440. doi:10.1002/jmv.25682
Jin, Y.H., Cai, L., Cheng, Z.S., Cheng, H., Deng, T., Fan, Y.P., Fang, C., Huang, D., Huang, L.Q., Huang, Q., Han, Y., Hu, B., Hu, F., Li, B.H., Li, Y.R., Liang, K., Lin, L.K., Luo, L.S., Ma, J., Ma, L.L., Peng, Z.Y., Pa, Y.B., Pan, Z.Y., Ren, X.Q., Sun, H.M., Wang, Y., Wang, Y.Y., Wang, H., Wei, C.J., Wu, D.F., Xia, J., Xiong, Y., Xu, H.B., Yao, X.M., Yuan, Y.F., Ye, T.S., Zhang, X.C., Zhang, Y.W., Zhang Y.G., Zhang, H.M., Zhao, Y., Zhao, M.J., Zi, H., Zeng, X.T., Wang, Y.Y., Wang, X.H., \& he Zhongnan Hospital of Wuhan University Novel Coronavirus Management and Research Team, EvidenceBased Medicine Chapter of China International Exchange and Promotive Association for Medical and Health Care. (2020). A rapid advice guideline for the diagnosis and treatment of 2019 novel coronavirus (2019-nCoV) infected pneumonia (standard version). Military Medical Research, 7, 4. doi:10.1186/s40779-020-0233-6

Klausegger, A., Strobl, B., Regl, G., Kaser, A., Luytjes, W., \& Vlasak, R. (1999). Identification of a Coronavirus Hemagglutinin-Esterase with a Substrate Specificity Different from Those of Influenza C Virus and Bovine Coronavirus. Journal of Virology, 73(5), 3737-3743

Krijnse-Locker, J., Ericsson, M., Rottier, P.J., \& Griffiths, G. (1994). Characterization of the Budding Compartment of Mouse Hepatitis Virus: Evidence That Transport from the RER to the Golgi Complex Requires Only One Vesicular Transport Step. The Journal of Cell Biology, 124(1), 55-70. doi:10.1083/jcb.124.1.55

Kumar, P., Ahmad, M.I., \& Singh, S. (2020). COVID-19: A devastating pandemic. Pharmaceutical Sciences, [Epub ahead of print], 1-26. doi:10.34172/PS.2020.34

Kuo, L. \& Masters, P.S. (2013). Functional analysis of the murine coronavirus genomic RNA packaging signal. Journal of virology, 87(9), 5182-5192. doi:10.1128/jvi.00100-13

Li, B.X., Ge, J.W., \& Li, Y.J. (2007). Porcine Aminopeptidase N Is a Functional Receptor for the PEDV Coronavirus. Virology, 365(1), 166-172. doi:10.1016/j.virol.2007.03.031

Li, H., Liu, S.M., Yu, X.H., Tang, S.L., \& Tang, C.K. (2020). Coronavirus disease 2019 (COVID-19): current status and future perspectives. International 
Journal of Antimicrobial Agents, 105951. doi:10.1016/j.jantimicag.2020.105951

Li, W., Moore, M.J., Vasilieva, N., Sui, J., Wong, S.K., Berne, M.A., Somasundaran, M., Sullivan, J.L., Luzuriaga, K., Greenough, T.C., Choe, H., \& Farzan, M. (2003). Angiotensin-converting Enzyme 2 Is a Functional Receptor for the SARS Coronavirus. Nature, 426(6965), 450-454. doi:10.1038/nature02145

Long, J.B. \& Ehrenfeld, J.M. (2020). The Role of Augmented Intelligence (AI) in Detecting and Preventing the Spread of Novel Coronavirus. Journal of Medical Systems, 44(3), 59. doi:10.1007/s10916-020-1536-6

Lu, R., Zhao, X., Li, J., Niu, P., Yang, B., Wu, H., Wang, W., Song, H., Huang, B., Zhu, N., Bi, Y., Ma, X., Zhang, F., Wang, L., Hu, T., Zhou, H., Hu, Z., Zhou, W., Zhao, L., Chen, J., Meng, Y., Wang, J., Lin, Y., Yuan, J., Xie, Z., Ma, J., Liu, W.J., Wang, D., Xu, W., Holmes, E.C., Gao, G.F., Wu, G., Chen, W., Shi, W., \& Tan W. (2020). Genomic characterisation and epidemiology of 2019 novel coronavirus: implications for virus origins and receptor binding. The Lancet, 395(10224), 565-574. doi:10.1016/S01406736(20)30251-8

McBride, R., van Zyl, M., \& Fielding, B.C. (2014). The coronavirus nucleocapsid is a multifunctional protein. Viruses, 6(8), 2991-3018. doi:10.3390/v6082991

Molenkamp, R. \& Spaan, W.J. (1997). Identification of a Specific Interaction Between the Coronavirus Mouse Hepatitis Virus A59 Nucleocapsid Protein and Packaging Signal. Virology, 239(1), 78-86. doi:10.1006/viro.1997.8867

Nedellec, P., Dveksler, G.S., Daniels, E., Turbide, C., Chow, B., Basile, A.A., Holmes, K.V., \& Beauchemin, N. (1994). Bgp2, a New Member of the Carcinoembryonic Antigen-Related Gene Family, Encodes an Alternative Receptor for Mouse Hepatitis Viruses. Journal of Virology, $68(7), 4525-4537$

Occupational Safety and Health Administration. (2020). COVID-19: Control and Prevention. https://www.osha.gov/SLTC/covid19/controlprevention.html

Okba, N.M.A., Muller, M.A., Li, W., Wang, C., GeurtsvanKessel, C.H., Corman, V.M.,
Lamers, M.M., Sikkema, R.S., de Bruin, E., Chandler, F.D., Yazdanpanah, Y., Hingrat, Q.L., Descamps, D., Houhou-Fidouh, N., Reusken, C.B.E.M., Bosch, B.J., Drosten, C., Koopmans, M.P.G., \& Haagmans, B.L. (2020). Severe Acute Respiratory Syndrome Coronavirus 2-Specific Antibody Responses in Coronavirus Disease 2019 Patients. Emerging Infectious Diseases, 26(7), [Epub ahead of print]. doi:10.3201/eid2607.200841

Oostra, M., Hagemeijer, M.C., van Gent, M., Bekker, C.P.J., te Lintelo, E.G., Rottier, P.J.M., \& de Haan, C.A.M. (2008). Topology and Membrane Anchoring of the Coronavirus Replication Complex: Not All Hydrophobic Domains of nsp3 and nsp6 Are Membrane Spanning. Journal of Virology, 82(24), 1239212405. doi:10.1128/jvi.01219-08

Porfidia, A. \& Pola, R. (2020). Venous thromboembolism and heparin use in COVID-19 patients: juggling between pragmatic choices, suggestions of medical societies. Journal of Thrombosis and Thrombolysis, [Epub ahead of print], 1-4. doi:10.1007/s11239-020-02125-4

Raj, V.S., Mou, H., Smits, S.L., Dekkers, D.H.W., Müller, M.A., Dijkman, R., Muth, D., Demmers, J.A.A., Zaki, A., Fouchier, R.A.M., Thiel, V., Drosten, C., Rottier, P.J.M., Osterhaus, A.D.M.E., Bosch, B.J., \& Haagmans, B.L. (2013). Dipeptidyl peptidase 4 is a functional receptor for the emerging human coronavirus-EMC. Nature, 495(7440), 251-254. doi:10.1038/nature12005

Schoeman, D. \& Fielding, B.C. (2019). Coronavirus envelope protein: current knowledge. Virology Journal, 16, 69. doi:10.1186/s12985-019-1182-0

Schultze, B. \& Herrler, G. (1992). Bovine Coronavirus Uses N-acetyl-9-O-acetylneuraminic Acid as a Receptor Determinant to Initiate the Infection of Cultured Cells. Journal of General Virology, 73(4), 901-906. doi:10.1099/0022-1317-73-4-901

Serrano, P., Johnson, M.A., Chatterjee, A., Neuman, B.W., Joseph, J.S., Buchmeier, M.J., Kuhn, P., \& Wüthrich, K. (2009). Nuclear Magnetic Resonance Structure of the Nucleic AcidBinding Domain of Severe Acute Respiratory Syndrome Coronavirus Nonstructural Protein 3. Journal of Virology, 83(24), 12998-13008. doi:10.1128/jvi.01253-09 
Shen, K., Yang, Y., Wang, T., Zhao, D., Jiang, Y., Jin, R., Zheng, Y., Xu, B., Xie, Z., Lin, L., Shang, Y., Lu, X., Shu, S., Bai, Y., Deng, J., Lu, M., Ye, L., Wang, X., Wang, Y., \& Gao, L. (2020). Diagnosis, Treatment, and Prevention of 2019 Novel Coronavirus Infection in Children: Experts' Consensus Statement. World Journal of Pediatrics, 7,1-9. doi:10.1007/s12519-020-003437

Singhal, T. (2020). A Review of Coronavirus Disease-2019 (COVID-19). Indian Journal of Pediatrics, 8(4), 281-286. doi:10.1007/s12098-020-03263-6

Sturman, L.S., Holmes, K.V., \& Behnke, J. (1980). Isolation of coronavirus envelope glycoproteins and interaction with the viral nucleocapsid. Journal of Virology, 33(1), 449-462

Taghizadeh-Hesary, F. \& Akbari, H. (2020). The powerful immune system against powerful COVID-19: A hypothesis. Medical Hypotheses, 140, 109762. doi:10.1016/j.mehy.2020.109762

Tooze, J., Tooze, S., \& Warren, G. (1984). Replication of Coronavirus MHV-A59 in Sac- Cells: Determination of the First Site of Budding of Progeny Virions. European Journal of Cell Biology, 33(2), 281-293

Trafton, A., Chu, J., \& Chandler, D.L. (2020). Covid-19 diagnostic based on MIT technology might be tested on patient samples soon. http://news.mit.edu/2020/covid-19diagnostic-test-prevention-0312

Tresnan, D.B., Levis, R., \& Holmes, K.V. (1996). Feline aminopeptidase $\mathrm{N}$ serves as a receptor for feline, canine, porcine, and human coronaviruses in serogroup I. Journal of Virology, 70(12), 8669-8674

Williams, R.K., Jiang, G.S., \& Holmes, K.V. (1991). Receptor for mouse hepatitis virus is a member of the carcinoembryonic antigen family of glycoproteins. Proceedings of the National Academy of Sciences of the United States of America, 88(13), 5533-5536. doi:10.1073/pnas.88.13.5533

World Health Organization. (2020). Coronavirus disease (COVID-19) technical guidance: Laboratory testing for 2019-nCoV in humans. https://www.who.int/emergencies/diseases /novel-coronavirus-2019/technicalguidance/laboratory-guidance
Worldometer. (2020). COVID-19 Coronavirus Pandemic. https://www.worldometers.info/coronaviru $\mathrm{s} /$

Wu, F., Zhao, S., Yu, B., Chen, Y.M., Wang, W., Song, Z.G., Hu, Y., Tao, Z.W., Tian, J.H., Pei, Y.Y., Yuan, M.L., Zhang, Y.L., Dai, F.H., Liu, Y., Wang, Q.M., Zheng, J.J., Xu, L., Holmes, E.C., \& Zhang, Y.Z. (2020a). A new coronavirus associated with human respiratory disease in China. Nature, 579(7798), 265-269. doi:10.1038/s41586-020-2008-3

Wu, R., Wu, L., Kuo, H.C.D., Shannar, A., Peter, R., Chou, P.J., Li, S., Hudlikar, R., Liu, X., Liu, Z., Poiani, G.J., Amorosa, L., Brunetti, L., \& Kong, A.N. (2020b). An Update on Current Therapeutic Drugs Treating COVID-19. Current Pharmacology Reports, [Epub ahead of print], 115. doi:10.1007/s40495-020-00216-7

Xu, X., Liu, Y., Weiss, S., Arnold, E., Sarafianos, S.G., \& Ding, J. (2003). Molecular Model of SARS Coronavirus Polymerase: Implications for Biochemical Functions and Drug Design. Nucleic Acids Research, 31(24), 7117-7130. doi:10.1093/nar/gkg916

Yavuz, S.S. \& Unal, S. (2020). Antiviral treatment of COVID-19. Turkish Journal of Medical Sciences, 50(3), 611-619. doi:10.3906/sag-2004-145

Yeager, C.L., Ashmun, R.A., Williams, R.K., Cardellichio, C.B., Shapiro, L.H., Look, A.T., \& Holmes, K.V. (1992). Human Aminopeptidase N Is a Receptor for Human Coronavirus 229E. Nature, 357(6377), 420-422. doi:10.1038/357420a0

Yi, Y., Lagniton, P.N.P., Ye, S., Li, E., \& Xu, R.H. (2020). COVID-19: what has been learned and to be learned about the novel coronavirus disease. International Journal of Biological Sciences, 16(10), 1753-1766. doi:10.7150/ijbs.45134

Yu, I.T.S., Li, Y., Wong, T.W., Tam, W., Chan, A.T., Lee, J.H.W., Leung, D.Y.C., \& Ho, T. (2004). Evidence of Airborne Transmission of the Severe Acute Respiratory Syndrome Virus. The New England Journal of Medicine, 350(17), 1731-1739. doi:10.1056/nejmoa032867

Zaki, A.M., van Boheemen, S., Bestebroer, T.M., Osterhaus, A.D.M.E, \& Fouchier, R.A.M. (2012). Brief Report: Isolation of a Novel Coronavirus from a Man with Pneumonia in 
Saudi Arabia. The New England Journal of Medicine, 369, 394. doi:10.1056/NEJMx130029

Zappa, A., Amendola, A., Romano, L., \& Zanetti, A. (2009). Emerging and re-emerging viruses in the era of globalization. Blood Transfusion, 7(3), 167-171. doi:10.2450/2009.0076-08

Zhang, Y., Chen, C., Zhu, S., Shu, C., Wang, D., Song, J., Song, Y., Zhen, W., Feng, Z., Wu, G., Xu, J., \& $\mathrm{Xu}, \mathrm{W}$. (2020a). Isolation of 2019-nCoV from a Stool Specimen of a Laboratory-Confirmed Case of the Coronavirus Disease 2019 (COVID-19). China CDC Weekly, 2(8), 123-124. doi:10.46234/ccdcw2020.033

Zhang, Y., Xu, Q., Sun, Z., \& Zhou, L. (2020b). Current targeted therapeutics against COVID-19: Based on first-line experience in China. Pharmacological Research, 157, 104854. doi:10.1016/j.phrs.2020.104854

Zhao, S., Lin, Q., Ran, J., Musa, S.S., Yang, G., Wang, M.H., Lou, Y., Gao, D., Yang, L., He, D., \& Wang, M.H. (2020). Preliminary Estimation of the Basic Reproduction Number of Novel Coronavirus (2019-nCoV) in China, From 2019 to 2020: A Data-Driven Analysis in the Early Phase of the Outbreak. International Journal of Infectious Diseases, 92, 214-217. doi:10.1016/j.ijid.2020.01.050

Zhejiang University School of Medicine. (2020). Handbook of COVID-19 Prevention and Treatment. Hangzhou, China: Zhejiang University School of Medicine.

Zheng, J. (2020). SARS-CoV-2: an Emerging Coronavirus that Causes a Global Threat. International Journal of Biological Sciences, 16(10), 1678-1685. doi:10.7150/ijbs.45053

Zhou, P., Yang, X., Wang, X. Hu, B., Zhang, L., Zhang, W., Si, H.R., Zhu, Y., Li, B., Huang, C.L., Chen, H.D., Chen, J., Luo, Y., Guo, H., Jiang, R.D., Liu, M.Q., Chen, Y., Shen, X.R., Wang, X., Zheng, X.S., Zhao, K., Chen, Q.J., Deng, F., Liu, L.L., Yan, B., Zhan, F.X., Wang, Y.Y., Xiao, G.F., \& Shi., Z.L. (2020). A pneumonia outbreak associated with a new coronavirus of probable bat origin. Nature 579(7798), 270-273. doi:10.1038/s41586-020-2012-7

Zhu, N., Zhang, D., Wang, W., Li, X., Yang, B., Song, J., Zhao, X., Huang, B., Shi, W., Lu, R., Niu, P., Zhan, F., Ma, X., Wang, D., Xu, W., Wu, G.,
Gao, G.F., Tan, W., \& China Novel Coronavirus Investigating and Research Team. (2020). A Novel Coronavirus from Patients with Pneumonia in China, 2019. The New England Journal of Medicine, 382(8), 727733. doi:10.1056/nejmoa2001017

Ziebuhr, J., Thiel, V., \& Gorbalenya, A. E. (2001). The Autocatalytic Release of a Putative RNA Virus Transcription Factor from Its Polyprotein Precursor Involves Two Paralogous Papainlike Proteases That Cleave the Same Peptide Bond. Journal of Biological Chemistry, 276(35), 33220-33232. doi:10.1074/jbc.m104097200

Züst, R., Cervantes-Barragan, L., Habjan, M., Maier, R., Neuman, B.W., Ziebuhr, J., Szretter, K.J., Baker, S.C., Barchet, W., Diamond, M.S., Siddell, S.G., Ludewig, B., \& Thiel, V. (2011). Ribose 2'-Omethylation Provides a Molecular Signature for the Distinction of Self and Non-Self mRNA Dependent on the RNA Sensor Mda5. Nature Immunology, 12(2), 137-143. doi:10.1038/ni.1979 